\title{
Are Founder CEOs Effective Innovators?
}

DOI:

10.1111/ajfs. 12217

\section{Document Version}

Accepted author manuscript

Link to publication record in Manchester Research Explorer

\section{Citation for published version (APA):}

Kim, J., \& Koo, K-J. (2018). Are Founder CEOs Effective Innovators? Asia-Pacific Journal of Financial Studies, 47(3), 426-448. https://doi.org/10.1111/ajfs.12217

\section{Published in:}

Asia-Pacific Journal of Financial Studies

\section{Citing this paper}

Please note that where the full-text provided on Manchester Research Explorer is the Author Accepted Manuscript or Proof version this may differ from the final Published version. If citing, it is advised that you check and use the publisher's definitive version.

\section{General rights}

Copyright and moral rights for the publications made accessible in the Research Explorer are retained by the authors and/or other copyright owners and it is a condition of accessing publications that users recognise and abide by the legal requirements associated with these rights.

\section{Takedown policy}

If you believe that this document breaches copyright please refer to the University of Manchester's Takedown Procedures [http://man.ac.uk/04Y6Bo] or contact uml.scholarlycommunications@manchester.ac.uk providing relevant details, so we can investigate your claim.

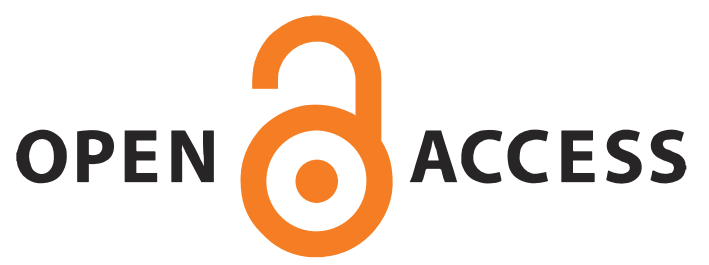




\title{
Are Founder CEOs Effective Innovators?
}

\author{
Jonghwan (Simon) Kim ${ }^{1}$ and KwangJoo Koo ${ }^{2, *}$
}

${ }^{*}$ Corresponding Author

Acknowledgments: We wish to thank two anonymous referees and the Special Issue Editor Xuan Tian for their valuable comments. We also thank Michael Paz for his helpful suggestions and comments. All errors are our own.

\footnotetext{
${ }^{1}$ Accounting and Finance Division, Alliance Manchester Business School, University of Manchester, Booth St E, Manchester M13 9SS, United Kingdom. Tel: 44-161-275-4020, email: jonghwan.kim@manchester.ac.uk

${ }^{2}$ Black School of Business, Pennsylvania State University-Erie, 5101 Jordan Road, Erie, PA 16563, United States. Tel: 1-814-898-6437, email: kuk244@psu.edu
} 


\title{
Are Founder CEOs Effective Innovators?
}

\begin{abstract}
This paper investigates the effectiveness of founder CEOs on firm innovation. We examine our research question using the number of patent citations as a proxy for firm innovation and a novel dataset of founder CEOs in S\&P 1500 firms over a 15-year period from 1994 through 2008. Our main results show that a founder CEO is associated with an increase in the citations, suggesting that founder CEOs are more effective in stimulating innovation compared to professional CEOs. Overall, these findings support the argument that a founder CEO plays an important role in facilitating firm innovation through more risk-taking efforts.
\end{abstract}

JEL Classification: L25; L26; M21; O32

Keywords: Founder CEOs; Professional CEOs; Innovation; Performance 


\section{Are Founder CEOs Effective Innovators?}

\section{Introduction}

The effects of founder CEOs, ${ }^{3}$ including those at Apple, Google, and Amazon, on developing and shaping corporate policies have been studied extensively in the academic literature (Anderson and Reeb, 2003; Nelson, 2003; Villalonga and Amit, 2006). In practice, the significance of this research is substantial as founder CEOs account for 12 to 13 percent of CEOs in public firms (Fahlenbrach, 2009; Villalonga and Amit, 2006). While founder CEOs are typically portrayed as highly motivated inventors who significantly impact firm outcomes (Wasserman, 2006), it remains unclear whether there is a distinct difference between founder CEOs and professional CEOs in terms of long-term firm innovation. ${ }^{4}$ Despite having demonstrated their technological innovativeness through founding a firm, there are at least two reasons why founder CEOs may not be effective innovators compared to professional CEOs. First, the managerial skills needed at the beginning stage of the company may not necessarily coincide with the skills needed to lead established firms in ways which spur innovation. (Jayaraman et al., 2000). Second, founder CEOs might be reluctant to adopt practices that standardize firm management, since these practices reduce both the founder's influence (Rajan, 2012) and the private benefits of control such influence (Bandiera et al., 2013). This paper addresses this gap in the literature by examining the impact of founder CEOs on long-term firm innovation outcomes.

\footnotetext{
${ }^{3}$ Founder CEOs are founding members of the firm, but professional CEOs joined firms after their founding (Villalonga and Amit, 2006).

${ }^{4}$ There are technological innovations and administrative innovations (Damanpour and Evan, 1984). We focus on technological innovation with the empirical proxy of citations and patent counts.
} 
Innovation is essential to the survival and evolution of firms in today's highly competitive environment. For instance, innovative products help differentiate products and services in the minds of customers. Innovative products and services are also a critical factor in turning one-time purchasers into brand loyal customers. This implies that firms' successes and survivals are based on their ability to meet demands for high-quality innovative outputs (Hannan and Freeman, 1989). To spur innovation, CEOs are playing critical roles (Elenkov and Manev, 2005; Mumford and Licuanan, 2004) by influencing firm decision-making on resource allocation and encouraging innovation (Schein, 1992; Yukl, 2002).

We advance two competing hypotheses which can potentially explain the impact of founder CEOs on innovation. First, entrepreneurship theory suggests that founder CEOs are better innovators than professional CEOs (Shane and Venkataraman, 2000). This stream of theory posits that founder CEOs have a stronger motivation to pursue long-term growth compared to their professional counterparts (Miller et al., 2011) and are likely to be risk takers (Fahlenbrach, 2009). Thus, founder CEOs, or entrepreneurs by their nature, are willing to take the significant risk of exploring new business opportunities through the development of novel products and services (Hirshleifer et al., 2012). On the contrary, corporate life cycle theory argues that founder CEOs have a lack of managerial abilities which limits firm innovation (Wasserman, 2012). It is assumed that founder CEOs may transfer the management in their possession to professional CEOs with better managerial skills as firms grow (Jain and Tabak, 2008). These arguments imply that firms with professional CEOs are likely to take more strategic risks and generate better innovation compared to firms with founder CEOs because of the high strategic risk involved in innovation-based projects. ${ }^{5}$

\footnotetext{
${ }^{5}$ The non-strategic exploration of innovation may potentially be very harmful since it requires the dedication of excessive resources by firms (Levinthal and March, 1993).
} 
We investigate these competing hypotheses using a novel dataset of founder CEOs in S\&P 1500 firms over a 15-year period from 1994 through 2008. Our proxy for firm innovation is the firm's citation count constructed based on the data developed by Kogan et al. (2017) ("KPSS" for short). ${ }^{6}$ We find that founder CEOs are positively associated with the number of citations after controlling for a number of firm characteristics, providing support for the entrepreneurship theory view of founder CEOs. We also find that CEOs are associated with stronger (weaker) innovation effects in more (less) competitive industries. Moreover, our findings show that firms led by founder CEOs demonstrate superior performance compared to firms led by professional CEOs (e.g., Adams et al., 2009; Villalonga and Amit, 2006). These results are robust to alternative measures of innovation. Additionally, we control for endogeneity concerns using a first-difference model which examines firms switching from founder CEOs to professional CEOs. These results confirm our main results. Taken together, the results are important in confirming that founder CEOs are effective as long-term firm innovators.

This paper makes two main contributions to the academic literature on entrepreneurship and innovation. First, our paper adds empirical evidence to the literature on CEO characteristics and their impact on innovation (Daily et al., 2002; Galasso and Simcoe, 2011). Our study also complements earlier studies that focus on the impact of institutional ownership (Aghion et al., 2013) and stock liquidity (Fang et al., 2014) on innovation. Second, we contribute to the literature on the role of founder CEOs, presenting direct evidence in support of the entrepreneurship theory view of founder CEOs and in opposition to the corporate life-cycle theory. Specifically, our study complements prior evidence that entrepreneurs are significant drivers of firm innovation (Drucker, 2002). More specifically, we provide evidence that firms

\footnotetext{
${ }^{4}$ Noah Stoffman provides their patent data at his personal webpage: http://kelley.iu.edu/nstoffma/.
} 
run by founder CEOs have superior long-term firm innovation outcomes compared to firms run by professional CEOs. Though previous research has provided that founder CEOs generate superior firm outcomes compared to professional CEOs, these studies do not consider long-term outcomes.

The rest of the paper proceeds as follows. Section 2 reviews the relevant literature and develops our hypotheses. Section 3 describes the data and research design. Section 4 presents our results and Section 5 concludes.

\section{Literature and Hypotheses}

\subsection{Entrepreneurship theory}

Founder CEOs are considered to be entrepreneurs. Schumpeter (1934) provides that an entrepreneur plays a crucial role by assimilating new knowledge and setting up new products. $\mathrm{He}$ also indicates that entrepreneurship is the actualization of innovation which is the center of firm growth. Drucker (2002) points out that, because innovation is the specific instrument of entrepreneurship, founder CEOs drive technological innovation. There are two reasons why founder CEOs are better innovators compared to professional CEOs. Founder CEOs are more willing to undertake risky projects with higher technological innovation (Barney, 1997; Schumpeter, 1934). However, professional CEOs are more risk-averse and are likely to exhibit conservative behaviors (Gibson and Sanbonmatsu, 2004). This implies that risky activities mainly would be taken not by professional CEOs but by founder CEOs with superior vision, experience, and willingness to take the risk (Schumpeter, 1934). Risk-taking is important in innovation as stepping stones because innovation needs a tolerance of high failure risk and should overcome a fear of failures (Hirshleifer et al., 2012; Schumpeter, 1934). Founder CEOs 
are able to handle the uncertainty that accompanies doing something in reality as opposed to professional CEOs.

Second, founder CEOs have a more long-term orientation compared to professional CEOs (Villalonga and Amit, 2006). Long-term goals are closely related to firms' innovation because more innovative ideas and projects take a longer time to be realized and produce beneficial outcomes. Furthermore, long-term incentives induce agents to exert effort toward innovation (Lerner and Wulf, 2007). This provides that short-term incentives provided to CEOs may discourage them from investing in innovation (Manso, 2011). Thus, firms led by founder CEOs with long-term horizon have greater innovation than firms led by professional CEOs with a short-term horizon.

\section{H1a: Under the entrepreneurship theory, a founder CEO exhibits stronger innovation performance than a professional CEO.}

\subsection{Life cycle theory}

The life cycle theory argues that founder CEOs may not have the managerial skills to manage their firms spurring innovations continuously, and thus do not fully meet the needs of growing firms (Boeker and Wiltbank, 2005). This theory also suggests that CEOs' skills to run complex management systems are essential for firms' survival and should evolve at different stages of a firm's life cycle (Jain and Tabak, 2008). As today's product markets become mature and saturated, the growth of firms run by founder CEOs seems to slow down (Jayaraman et al., 2000). As firms grow, their founders' abilities to maintain further growth and generate innovation deteriorate. For the reason, large established firms likely have gone through management transitions due to changes in the ownership and governance (Jain and Tabak, 2008).

At the mature stage, firms start to distribute their earnings to their shareholders. When firms are on the brink of becoming stagnant, firms would consider changing management 
practices. Finally, the environment of large established firms is likely to pressurize founders to step down from the CEO's position and replace them with professional CEOs (Boeker and Fleming, 2010). Wasserman (2003) empirically shows that as firms grow, founder CEOs are indeed replaced by professional CEOs. Change in leadership and CEO characteristics can be beneficial when firms get into a new level. This implies that the larger established firms require different management characteristics, though founder CEOs have entrepreneurial characteristics. Thus, founder CEOs' management skills may be inappropriate to run large firms (Boeker and Wiltbank, 2005). Overall, the theory supports that large established firms run by founder CEOs exhibit weak innovation performance because of their incompatible skill sets. This leads to the following hypothesis:

\section{H1b: Under the life cycle theory, a founder CEO exhibits weaker innovation performance than a professional CEO.}

\subsection{Risk-taking hypothesis}

Founder CEOs are the most powerful persistent figures with considerable influence on board decisions, duality structure, and long-term affiliation due to their entrepreneur status (Anderson et al., 2009; Fahlenbrach, 2009). The extraordinary influence has a dominant effect on firm management and control. Due to their power, founder CEOs can easily facilitate their control of firms' decision-making (Adams et al., 2005). Powerful founder CEOs are likely to avoid the balanced decisions with other executives, resulting in more extreme firm decisions-of which the outcomes may be either positive or negative-than the consensus reached among the top management team. Thus, previous research on the effects of founder CEOs control on firm performance is mixed. Villalonga and Amit (2006) provide a positive relation between founder CEOs and firm performance. In contrast, Morck et al. (1998) find a negative correlation between their control in Canadian firms and firm performance. 
Founder CEOs, in general, take the long-term views with higher risks rather than shortterm oriented actions (Fahlenbrach, 2009). CEOs should resolve the uncertainty in the development of new products and services which are at their early stage of revenue generation. To alleviate the uncertainty, they have different approaches to the risk of each uncertainty. The extreme power of founder CEOs brings unbalanced decision towards risk, leading to risky investment projects (Fahlenbrach, 2009). They are likely to commit taking risky channels by joining the industry with higher litigation risk and the demand for advanced technology. If so, we expect the positive moderating effects of the riskier channels between founder CEOs and innovation performance.

\section{H2: The effect of a founder CEO on innovation is pronounced when firms are facing higher litigation risk.}

\section{Data and Methodology}

\subsection{Data}

Our initial sample comes primarily from ExecuComp and the patent data constructed by Kogan et al. (2017) based on US Patent and Trademark Office's (USPTO) database. We collect accounting information from Compustat, institutional ownership information from Thomson CDA/Spectrum 13F Holdings, and corporate governance index in the Investor Responsibility Research Center (IRRC). To identify the main independent variable, we hand-collected data on the identities of founder CEOs studying SEC filings, web-based biographical information (e,g, NNDB, Bloomberg Businessweek, Forbes), and official websites for sample firms. The KPSS data provide information on all patents from 1926 to 2010. With the knowledge of potential bias due to data truncation, we require three future years of citation accumulation to construct our innovation proxy, and limit the analysis period to end in 2008. To test our hypotheses, we use a forward structure so that the innovation output is measured up to over three years (years $t$ 
through $t+2$ ) from the focal year (year $t$ ). The final unbalanced panel sample consists of 12,146 firm-year observations with 2,106 unique firms from 1994 to 2008 . We exclude financial firms (SIC codes between 6000 and 6999) and firm-year observations with missing accounting, financial, and other relevant data.

\subsection{Variables}

The key independent variable of this study is Founder CEO. To build the data, we conducted Internet searches through CEOs' profile pages on Bloomberg Businessweek, Forbes, and Google, among others. Using this manual and labor-intensive process, we found 3,783 founder CEOs, which comprise approximately 26.7 percent of our sample. The variable is a dichotomous variable, with zero representing a professional CEO, i.e., a non-founder, and one representing a founder CEO.

We use innovation output (patent-based metrics) as a proxy for innovation performance instead of innovation input (R\&D expenditures) for two reasons. First, R\&D expenditures are sensitive to accounting norms as argued by Acharya and Subramanian (2009) and it is debatable whether it should be capitalized or expensed whereas patent-based metrics reflect the success of both observable and unobservable innovation inputs. Second, given a firm's innovation input, the number of patents captures its overall innovation productivity and the number of citations per patent captures the significance and quality of its innovation output. In particular, we use the new patent database developed by Kogan, Papanikolaou, Seru, and Stoffman (2017). ${ }^{7}$ There is a time lag between the application year and grant year. Thus, to accommodate the painful innovation process and its effects, we include a long-horizon innovation performance as a sum of the citation counts for the focal year over three years from year $t+1$ to $t+3$ ("total citations $3 y r$ ") to

\footnotetext{
${ }^{7}$ We use the updated patent counts and citations used in Kogan et al. (2017) and available at Noah Stoffman's web page (http://kelley.iu.edu/nstoffma).
} 
use a forward structure. Also, to confirm our findings, we employ alternative innovation measures. First, we differentiate the values of citations received by other firms because non-self citations $^{8}$ are more valuable to the patenting firm and leads to a higher commercial value of innovation (Faleye et al., 2011). The non-self-citations represents expansion to other new areas that the firms have not explored. Second, we count the number of preceding patents that are cited in a patent's application ("backward citation"9) (Lanjouw and Schankerman, 2004). More backward citations are likely to lead a firm's innovation in relatively mature technologies areas (Lanjouw and Schankerman, 2001). Lastly, to understand the economic impacts of founder CEOs on innovation, we consider the KPSS's economic value of patents. ${ }^{10}$ These measures would capture the quality and quantity of innovation by considering the various dimensions of firm innovation outputs (Balsmeier et al., 2017).

Moreover, based on the literature (e.g., Aghion et al., 2013; Balkin et al., 2000; Balsmeier and Buchwald, 2015; Faleye et al., 2014; Hirshleifer et al., 2012; Hundley et al., 1996), we include the following control variables: Size (the natural logarithm of book-value of assets), Firm age (the natural logarithm of the number of the year since the first appearance in CRSP), Tobin's Q, Stock return, ROA, Leverage (total debt/total assets), Capex (capital expenditures/total assets), $R \& D$ Intensity ( $R \& D$ expenditures/the book value of total assets), Cash (the natural logarithm of cash in millions ), Institutional holdings (the shares held by institutional investors as a fraction of shares outstanding), E-index (Bebchuk et al.'s (2009) Entrenchment index), CEO age and gender (Barker III \& Mueller, 2002), CEO tenure (the number of years the CEO has been on the job),

\footnotetext{
${ }^{8}$ Non-self-citations are those received the other firms. In regression models, we take the log of citations: e.g., $\operatorname{Ln}($ citations +1$)$.

${ }^{9}$ Using the same patent data, we calculate the number of prior patents being cited in a patent's application and summarize it at a firm-year level.

${ }^{10}$ The estimated economic value of patents calculated based on the stock-market reactions to a firm's patent grant.
} 
$C E O$ duality (A dummy equal to one if the CEO is chairperson of the firm's board) and $C E O$ holidngs (the proportion of outstanding shares owned by the corporate CEO in a given year). CEOs are likely to have a long-term orientation when their interests and wealth are well-aligned with those of shareholders. Consistent with prior studies (e.g., Barker III and Mueller, 2002, Hirshleifer et al., 2012), we, therefore, include CEO delta (change in the dollar value of the CEO wealth for a one percentage point change in stock price at the end of the fiscal year) and $C E O$ compensation (TDC1 in ExecuComp). Moreover, to capture the variations over time and across industries, we include year and industry dummies (based on the first two digits of the SIC) and $H H I$ (Herfindhal-Index: the sum of the squared proportion of total industry sales that is represented by each firm in an industry with a four-digit SIC).

Table 1 presents the summary statistics of our variables. In Panel A, the mean of KPSS total citations is 227 . The average non-self citation count is 148 , while the other 79 citations are received from themselves. On average, a patent refers backward to 299 prior arts. The average economic value of patents applied in a year is about $\$ 384$ million. Out of the sample, 21.8 percent are founder CEO-years (standard deviation of 0.405). Panel B compares the differences in the key research variables between firms with founder CEOs and those with professional CEOs. Not surprisingly, the firms with founder CEOs have significantly larger innovation outputs in all measures (i.e., Citations, Patent applications, Non-self citations, Backward citations, Economic value). In addition, we also find that founder CEOs manage younger and smaller firms and firms with lower leverage ratios, better performance (i.e., higher Tobin's Q and higher ROA), and accept lower compensation.

Insert Table 1 about here.

\subsection{Research design}


In this section, we test whether founder CEOs lead better innovation performance compared to professional CEOs. We mainly use the fixed effects regressions to account for the effects of unobserved firm-specific factors, considerable within-panel variation in the variable (Wooldridge, 1995). We also use Tobit regression models, since our dependent variable always carries non-negative values (i.e., with the lower bound of zero), and 65 percent of our firm-year observations have zero KPSS citations (i.e., with a highly skewed distribution). We estimate founder CEOs' effects on innovation by estimating the following base-line regression:

$$
\text { Innovation }_{i}=\alpha+\beta \times \text { FounderCEO }_{i}+\mu \times \text { Control }_{i}+\varepsilon_{i}
$$

\section{Empirical Results and Robustness Checks}

\subsection{Main results}

Table 2 reports the results from fixed effects regressions and Tobit regressions of innovation on founder CEOs in different combinations of differential innovation measures (i.e., Citations, Patents, R\&D intensity, Economic values, Backward citations, and Non-self-citations). We present fixed effects panel OLS estimation outcomes in Panel A, and repeat the regressions with Tobit in Panel B. For both models, we cluster robust standard errors at a firm level and include year and industry dummies ${ }^{11}$ to control for potential common shocks.

Table 2 shows the results of baseline regression where we find founder CEOs bring significantly more innovations. With our main dependent variable of Citations, we find strong statistical significance from total citations and the coefficients $(\beta=0.135 ; t$-stat $>2.48)$, are sizeable, which yields economic significance as well. It provides that the presence of founder CEOs leads to approximately 14 percent more citations in a year. The results with alternative patent-based innovation proxies provide strong support for the finding. In particular, we find

\footnotetext{
${ }^{11}$ We define 48 industries following Fama and French.
} 
sizeable and significant effects of founder CEOs from Columns 2 to 4 (Patents, Economic values, and Backward citations). Notably, the regression of economic values (Column 3) presents the largest coefficients in all models $(\beta=0.227 ; t$-stat $>3.81)$. That is, the economic value of patents created in founder CEO firms is larger than that in firms with professional CEOs approximately by 22.7 percent, which indicates economic significance. In Columns 5 and 6, we find consistently positive effects that are, however, insignificance.

The Tobit models in Panel B confirm the findings from the OLS models. In all regressions of patent-based metrics, the coefficients on founder CEOs carry positive and significant signs ( $t$-stat $>1.96$ for all models). Unlike the result of the fixed effect OLS outcomes, the Tobit specification shows even larger coefficients (and thus estimated effect size) of founder CEOs, and picks up statistical significance of founder CEOs for non-self-citations in Column 5 ( $\beta=0.254 ; t$-stat $>2.54)$. Still, despite the positive sign, we have little evidence of the effects on R\&D intensity (Column 6). In sum, Table 2 supplies consistent and strong evidence that the presence of founder CEO is significantly positively associated with innovation measured with different proxies. Hence, the findings strongly support Hypothesis 1a, the entrepreneurship theory that founder CEOs with a more aggressive risk preference are indeed willing to take strategic entrepreneurial risks and, consequently, spur more innovation than professional CEOs who are presumably less risk-seeking (inversely more risk-averse).

Insert Table 2 about here.

\subsection{First-difference regressions}

To shed further light on whether founder CEOs influence innovation, we employ firstdifference regression models that are designed to capture the effect on the changes in the firm type-switching from a founder CEO firm to the other. The results of this design are reported in 
Table 4. The variable Founder CEO 1 to 0 identifies firms as they change from having founder CEOs to having professional CEOs. Panel A shows that the difference in means of Accumulated Total Citations for three years between $t+1$ through $t+3$ (Column 1) and between $t$ through $t+2$ (Column 2) decreases by 23.3 percent and 12.7 percent respectively when founders step down from the CEO position in Year $t$. Panel B reports the consistent results using alternative measures of innovation. In particular, we find negative coefficients on the CEO turnover event in all models and find significance in all but economic value model (Column 3 ). With the alternative design, we continue to observe a positive and significant relationship between founder CEOs and innovation outputs, showing that firms run by founder CEOs exhibit more innovation relative to firms run by professional CEOs. These results provide stronger support for our H1a.

Insert Table 3 about here.

4.3 Channels: The moderating effects of risk-taking and new technology

To further investigate the driving mechanisms through which founder CEOs improve the firms' innovation outcomes, we develop our predictions regarding the moderating effects of (1) an industry characteristic-greater innovation-intensity-and (2) litigation risk on the relationship between founder CEOs and innovation performance. Tables 4 and 5 report the respective results. In particular, Table 4 provides the interaction effects between founder CEO and a dummy for new economy ${ }^{12}$ firms that are more R\&D intense and innovation-driven. The table reports the

\footnotetext{
${ }^{12}$ Ittner, Lambert, and Larcker (2003), and Murphy (2003) define new economy firms as those exploiting the rapid technological development. Murphy (2003), in particular, classifies them using their primary SIC codes. They are 3570 (Computer and Office Equipment), 3571 (Electronic Computers), 3572 (Computer Storage Devices), 3576 (Computer Communication Equipment), 3577 (Computer Peripheral Equipment), 3661 (Telephone \& Telegraph Apparatus), 3674 (Semiconductor and Related Devices), 4812 (Wireless Telecommunication), 4813 (Telecommunication), 5045 (Computers and Software Wholesalers), 5961 (Electronic Mail-Order Houses), 7370 (Computer Programming, Data Processing), 7371 (Computer Programming Service), 7372 (Prepackaged Software), and 7373 (Computer Integrated Systems Design).
} 
following. First, founder CEOs in all models is significantly positive except for patents granted. Second, it is no surprise that the new economy firm indicator is positive for all models, indicating greater innovation in new economy firms. Third, the interaction effects of new economy in both panels are positive and significant (for example, $\beta=0.454$; $t$-stat $=4.52$ in Panel A) except for the economic values of patents. The findings from Table 4 are a clear indication of the significantly more pronounced effect of founder CEOs in more technology-intense industries.

Insert Table 4 about here.

According to the agency theory, without proper oversight, managers will shirk their responsibilities by reducing their risk-taking behaviors (Jensen and Meckling, 1976). The threat of litigation risks mitigates agency issues for risk-taking and might keep founder CEOs focused on innovative activities. To strengthen our argument of founder CEOs' risk-taking and its effect on innovation, we investigate how founder CEOs improve the firms' innovation outcomes by exploring the interaction effects of litigation risk and founder CEO. As firms' litigation risk captures the degree of risk in firm decisions, we estimate the litigation risk (Kim and Skinner, 2012) which leads to a large and sudden decline in stock price. Table 5 reports the interaction effects of litigation risk. Consistent with our prediction that founder CEOs take are likely to join the industry with higher litigation risks, the coefficients on the interaction terms are positive and significant in all the regressions of the number of citations $(\beta=0.457 ; t$-stat $=4.81$ in Panel $\mathrm{A})$ and the alternative innovation proxies (Panel B). This supports our argument of the founder CEOs' risk-taking channel, suggesting that firms with founder CEOs don't hesitate to join the industries with higher litigation risks.

Insert Table 5 about here. 
As we have shown, founder CEOs likely generate more useful innovations (i.e., patents with more citations) by spontaneously taking the risk of innovative projects, which, however, may not always lead to a higher firm value. Table 6 presents the evidence that the presence of founder CEOs affect firm value through risk-taking behaviors and innovation. Panel A shows the regression of firm value, measured in Tobin's Q, on the dummy for founder CEOs and firm litigation risk. The interaction term between them has a strong positive relationship with firm value even though each variable is not significant. Panel B shows the effects of founder CEOs with innovation performance on firm value. The interaction term also shows a strong positive relationship with firm value even though each variable is not significant. In sum, founder CEOs spur firm value by generating risk-taking innovation.

Insert Table 6 about here.

\subsection{Robustness checks}

The empirical results may face a selection bias issue as firms make an endogenous decision over their CEO type (i.e., founder CEOs or professional CEO). To address the concern, we use the propensity score matching (PSM) method (Rosenbaum and Rubin, 1983). The PSM may mitigate the endogeneity issues stemming from a selection bias. We use a probit model to estimate propensity scores, or the probability, of a CEO-switching event. The estimation model includes all the control variables as used in Table 2. Table 7 estimates the average treatment effects (ATE) and shows statistically significant and positive difference in Patents $(t$-stats=1.66) and Backward citations $($ t-stats $=1.79)$ and marginally insignificant in Citations ( $t$-stats $=1.64)$. This result confirms our main results, controlling for the selection bias.

Insert Table 7 about here. 
To enrich the empirical results, we run additional tests for subsamples of firms with relatively longer- and shorter-tenured CEOs. In general, CEOs are likely to stay in their firms as a CEO when they can increase their wealth by increasing higher growth opportunities. We split our sample observations into two groups of firms with founder CEOs whose tenure in a firm is longer and shorter than the median CEO tenure. Table 8 finds that the effect of founder CEOs on firm innovation exists only in the subset of CEOs with a relatively shorter tenure. In particular, Panel B reports a positive and significant coefficient on the dummy $(\beta=0.287 ; t$-stat $=2.05)$, while it is not in Panel $\mathrm{A}(\beta=0.135 ; t$-stat $=0.67)$. The finding is consistent across all the alternative innovation measures. The finding provides that the founder CEOs' relative advantage from the unique and competitive skill set in promoting firm innovation wanes away as their counterparts or professional CEOs learn more about firm idiosyncrasy and innovative processes.

Insert Table 8 about here.

\section{Conclusion}

CEO evolution is not only a microeconomic issue but also a society-wide issue that market participants are interested in. To shed light on this issue, we investigate the effect of founder CEOs on firm innovation. In this study, we discuss two competing perspectives fueling the debate on the effects of founder CEOs on long-term firm outcomes. While the entrepreneurship theory and the life cycle theory provide the relationship between the CEO type and innovation performance, this relationship has been mixed theoretically. To better understand the mixed predictions in innovation performance between firms run by founder CEOs and those run by professional CEOs, we use the number of patent citations and applications as proxies for innovation. Using a dataset on S\&P 1500 firms between 1994 and 2008, we find that founder CEOs are positively and significantly associated with innovation performance, which is 
consistent with the prediction in the entrepreneurship theory. We also find that innovation performance becomes weaker when firms switch from having founder CEOs to having professional CEOs. In addition, the effect of founder CEOs is even stronger in new economy industries which require substantial technological developments and in business with higher litigation risks. This implies that founder CEOs spur innovation and firm value by making more risk-taking efforts. Our findings are robust to subsequent tests, including alternative measures of innovation performance, and alternative model specifications. Overall, our study provides that founder CEOs have a significant effect on innovation performance and firm value. Therefore, firms should consider the strengths and weakness of each CEO type when they make a decision over the replacement of founder CEOs to professional ones in pursuit of further corporate innovation.

\section{References}

Acharya, V., and K.V. Subramanian, 2009, Bankruptcy codes and innovation, Review of Financial Studies 22, pp.4949-4988.

Adams, R., H. Almeida, and D. Ferreira,2005, Powerful CEOs and Their Impact on Corporate Performance, Review of Financial Studies 18, pp.1403-1432.

Adams, R., H. Almeida, and D. Ferreira, 2009, Understanding the relationship between founderCEOs and firm performance, Journal of Empirical Finance 16, pp.136-150.

Aghion, P., J. Van Reenen, and L. Zingales, 2013, Innovation and institutional ownership, The American Economic Review 103, pp.277-304.

Anderson, R.C., and D.M. Reeb, 2003, Founding-family ownership and firm performance: Evidence from the S\&P 500, Journal of Finance 58, pp.1301-1328.

Anderson, R.C., Duru, A., and D.M. Reeb, 2009, Founders, heirs, and corporate opacity in the United States, Journal of Financial Economics 92, pp.205-222.

Balkin, D.B., G.D. Markman, and L. R. Gomez-Mejia, 2000, Is CEO pay in high-technology firms related to innovation? Academy of management journal, 43, pp.1118-1129. 
Balsmeier, B., and A. Buchwald, 2015, Who promotes more innovations? Inside versus outside hired CEOs, Industrial and Corporate Change 24, pp.1013-1045.

Balsmeier, B., Fleming, L., and Manso, G., 2017. Independent boards and innovation. Journal of Financial Economics 123, pp. 536-557.

Bandiera, O., A. Prat, and R. Sadun R, 2013, Managing the Family Firm: Evidence from CEOs at Work, NBER Working Paper. National Bureau of Economic Research: Cambridge, MA.

Barney, J.,1997, Gaining and sustaining Competitive Advantage. (MA: Addison-Wesley).

Boeker, W., and B. Fleming, 2010, Parent firm effects on founder turnover: Parent success, founder legitimacy, and founder tenure, Strategic Entrepreneurship Journal 4, pp. 252-267.

Boeker, W., and R. Wiltbank, 2005, New venture evolution and managerial capabilities. Organizational Science16, pp.123-133.

Daily, C.M., P.P. McDougall, J.G. Covin, and D.R. Dalton, 2002, Governance and Strategic Leadership in Entrepreneurial Firms, Journal of Management 28, pp. 387-412

Damanpour, F., and W.M. Evan, 1984, Organizational innovation and performance: the problem of "organizational lag." Administrative science quarterly 29, pp. 392-409.

Drucker, P., 2002, Managing in the Next Society. (Truman Talley, New York)

Elenkov, D. S., and I.M. Manev, 2005, Top management leadership and influence on innovation: The role of socio-cultural context. Journal of Management 31, pp. 381-402.

Fahlenbrach, R, 2009, Founder-CEOs, investment decisions, and stock market performance. Journal of Financial and Quantitative Analysis 44, pp. 439-466.

Faleye, O., T. Kovacs, and A.Venkateswaran, 2014. Do better-connected CEOs innovate more? Journal of Financial and Quantitative Analysis 49, pp.1201-1225.

Fang, V.W., X. Tian, and S. Tice, 2014, Does stock liquidity enhance or impede firm innovation? Journal of Finance 69, pp. 2085-2125.

Fahlenbrach, R., 2009, Founder-CEOs, Investment Decisions, and Stock Market Performance, Journal of Financial and Quantitative Analysis 44, pp.439-466.

Faleye, O., Hoitash, R., and Hoitash, U., 2011, The costs of intense board monitoring. Journal of Financial Economics 101, pp. 160-181.

Galasso, A., and T.S. Simcoe, 2011, CEO overconfidence and innovation, Management Science 57, pp.1469-1484.

Gibson, B., and D.M. Sanbonmatsu, 2004, Optimism, pessimism, and gambling: The downside of optimism. Personality and Social Psychology Bulletin 30, pp.149-160. 
Hall, B.H., A. Jaffe, and M. Trajtenberg, 2001, The NBER patent citation data file: Lessons, insights and methodological tools, National Bureau of Economic Research.

Hall, B.H., A. Jaffe, and M. Trajtenberg, 2005. Market value and patent citations. RAND Journal of Economics 36, pp.16-38.

Hannan, M.T., and J. Freeman. 1989. Organization ecology. (Harvard University Press, Cambridge).

Hirshleifer, D., A. Low, and S.H. Teoh, 2012, Are overconfident CEOs better innovators? Journal of Finance 67, pp.1457-1498.

Jain, B.A., and F.Tabak, 2008, Factors influencing the choice between founder versus nonfounder CEOs for IPO firms. Journal of Business Venturing 23,pp. 21-45.

Jayaraman, N., A. Khorana, E. Nelling, and J. Covin, 2000, CEO founder status and firm financial performance. Strategic Management Journal 21, pp. 1215-1224.

Jensen, M. C., and Meckling, W.H., 1976, Theory of the firm: Managerial behavior, agency costs and ownership structure. Journal of Financial Economics 3, pp. 305-360.

Kim., I., and Skinner, D.,2012, Measuring securities litigation risk, Journal of Accounting and Economics 53, pp. 290-310.

Kogan, L., D. Papanikolaou, A. Seru, and N. Stoffman, 2017, Technological innovation, resource allocation, and growth, The Quarterly Journal of Economics, 132(2), pp. 665712.

Lanjouw, J.O., and Schankerman, M., 2001, Characteristics of patent litigation: a window on competition. Rand Journal of Economics, pp. 129-151.

Lerner, J., and J.Wulf, 2007, Innovation and incentives: Evidence from corporate R\&D, The Review of Economics and Statistics 89, pp.634-644

Manso, G., 2011, Motivating innovation, Journal of Finance 66, pp.1823-1860.

Morck, R., D. Strangeland, and B. Yeung, 1998, Inherited Wealth, Corporate Control and Economic Growth: a Canadian Disease? NBER Working paper, no. 6814.

Levinthal, D.A., and J.G. March, 1993, The myopia of learning, Strategic Management Journal 14, pp. 95-112.

Miller, D., L. Breton-Miller, and R.H. Lester, 2011, Family and lone founder ownership and strategic behaviour: Social context, identity, and institutional logics, Journal of Management Studies 48, pp. 1-25.

Mumford, M. D., and B. Licuanan, 2004, Leading for innovation: Conclusions, issues, and directions. Leadership Quarterly 15, pp. 163-171. 
Nelson, T., 2003, The persistence of founder influence: Management, ownership, and performance effects at initial public offering, Strategic Management Journal 24, pp.707724.

Rajan, R.G., 2012, The Corporation in Finance, Journal of Finance 67, pp. 1173-1217.

Schein, E., 1992, Organizational Culture and Leadership, (San Francisco, CA, Jossey-Bass)

Schumpeter, J.A. 1934, The theory of economic development: An inquiry into profits, capital, credit, interest, and the business cycle, Transaction publishers.

Shane,S., and Venkataraman, S., 2000, The promise of entrepreneurship as a field of research, The Academy of Management Review 25, pp. 217-226.

Villalonga, B., and R. Amit, 2006, How do family ownership, control and management affect firm value? Journal of Financial Economics 80, pp. 385-417.

Wasserman, N., 2003, Founder-CEO succession and the paradox of entrepreneurial success, Organization Science 14, pp. 149-172.

Wasserman, N., 2006, Stewards, Agents, and the Founder Discount: Executive Compensation in New Ventures. Academy of Management Journal 49, pp. 960-976.

Wasserman, N., 2012, The Founder's Dilemmas: Anticipating and Avoiding the Pitfalls That Can Sink a Startup: Anticipating and Avoiding the Pitfalls That Can Sink a Startup. (Princeton University Press, Princeton)

Wooldridge, J.M.,1995, Selection Corrections for Panel Data Models under Conditional Mean Independence Assumptions, Journal of Econometrics 68, pp.115-132.

Yukl, G.A., 2002. Leadership in organizations, Upper Saddle River, (NJ: Prentice-Hall) 
Table 1 Descriptive Statistics $(N=12,146)$

Panel A: The Full Sample

\begin{tabular}{|c|c|c|c|c|}
\hline $\begin{array}{r}\text { Variables } \\
\end{array}$ & Mean & Std. Dev. & Min & $\operatorname{Max}$ \\
\hline Citations & 201.282 & $1,395.298$ & 0.000 & 65,315 \\
\hline Patents & 22.356 & 105.615 & 0.000 & 4,372 \\
\hline Non-self-citations & 148.515 & $1,285.335$ & 0 & 69,963 \\
\hline Backward citations & 298.576 & $1,616.335$ & 0 & 66,257 \\
\hline Economic value & 383.905 & $2,580.256$ & 0 & 112,235 \\
\hline Founder CEO & 0.218 & 0.405 & 0.000 & 1.000 \\
\hline CEO holdings & 0.022 & 0.059 & 0.000 & 0.872 \\
\hline $\mathrm{Ln}(\mathrm{CEO}$ tenure $)$ & 1.793 & 0.945 & 0.000 & 3.942 \\
\hline Female CEO & 0.017 & 0.1167 & 0 & 1 \\
\hline CEO Delta & 7.089 & 8.564 & 0.000 & 11.928 \\
\hline E Index & 2.429 & 1.306 & 0.000 & 6.000 \\
\hline Ln (CEO Compensation) & 7.714 & 1.153 & 0 & 12.945 \\
\hline R\&D Intensity & 0.100 & 2.012 & 0.000 & 235.235 \\
\hline Tobin’s q & 2.003 & 2.374 & 0.298 & 105.090 \\
\hline Herfindahl index & 0.106 & 0.092 & 0.019 & 0.945 \\
\hline ROA & 0.109 & 0.145 & -2.111 & 6.016 \\
\hline Cash & 0.133 & 0.154 & 0.000 & 0.924 \\
\hline CapEx & 0.051 & 0.053 & -0.174 & 0.820 \\
\hline Leverage & 0.227 & 0.245 & 0.000 & 1.000 \\
\hline Firm age & 23.842 & 17.967 & 0.000 & 83.000 \\
\hline Institutional holdings & 0.624 & 0.235 & 0.000 & 1.812 \\
\hline CEO duality & 0.601 & 0.488 & 0.000 & 1.000 \\
\hline Size & 7.102 & 1.803 & 0 & 11.836 \\
\hline
\end{tabular}


Panel B: Means of the variables across Founder CEO and Professional CEO

\begin{tabular}{|c|c|c|c|c|c|}
\hline \multirow[b]{2}{*}{ Variables } & \multicolumn{2}{|c|}{$\begin{array}{c}\text { Professional CEO } \\
\mathrm{N}=8,992\end{array}$} & \multicolumn{2}{|c|}{$\begin{array}{c}\text { Founder CEO } \\
\mathbf{N}=\mathbf{3 , 1 5 4}\end{array}$} & \multirow{2}{*}{$\begin{array}{c}\text { Differences } \\
\text { in Means }\end{array}$} \\
\hline & Mean & Std. Dev. & Mean & Std. Dev. & \\
\hline $\log ($ Citations +1$)$ & 1.035 & 2.090 & 1.161 & 2.145 & $0.121^{* * *}$ \\
\hline $\log ($ Patents +1$)$ & 0.741 & 1.310 & 1.019 & 1.604 & $0.278^{* * *}$ \\
\hline Non-self-citations & 161.436 & 10.146 & 419.274 & 17.479 & $257.835^{* * *}$ \\
\hline Backward citations & 177.084 & 11.421 & 498.758 & 21.932 & $321.674^{* * *}$ \\
\hline Economic value & 126.603 & 16.520 & 569.614 & 30.281 & $443.010^{* * *}$ \\
\hline CEO holdings & 0.015 & 0.049 & 0.056 & 0.086 & $0.041^{* * *}$ \\
\hline $\mathrm{Ln}(\mathrm{CEO}$ tenure $)$ & 1.499 & 0.804 & 2.678 & 2.287 & $1.179^{* * *}$ \\
\hline Female CEO & 0.018 & 0.001 & 0.015 & 0.001 & $-0.003^{* * *}$ \\
\hline Log(Delta) & 6.814 & 8.476 & 7.703 & 9.304 & $0.889^{* * *}$ \\
\hline E Index & 2.482 & 1.302 & 2.16 & 1.353 & $-0.322^{* *}$ \\
\hline Ln (CEO Compensation) & 7.903 & 1.138 & 7.536 & 1.246 & $-0.367^{* * *}$ \\
\hline R\&D Intensity & 0.098 & 2.412 & 0.103 & 1.158 & $0.005^{* * *}$ \\
\hline Tobin’s q & 1.864 & 0.010 & 2.434 & 0.047 & $0.570^{* * *}$ \\
\hline Herfindahl index & 0.109 & 0.099 & 0.104 & 0.081 & $-0.005^{*}$ \\
\hline ROA & 0.106 & 0.122 & 0.116 & 1.722 & $0.010^{* * *}$ \\
\hline Cash & 0.119 & 0.153 & 0.169 & 0.197 & $0.050^{* *}$ \\
\hline CapEx & 0.043 & 0.032 & 0.064 & 0.072 & $0.021^{* * *}$ \\
\hline Leverage & 0.244 & 0.194 & 0.207 & 0.212 & $-0.037^{* *}$ \\
\hline Firm age & 30.050 & 20.014 & 10.007 & 9.437 & $-20.043^{* * *}$ \\
\hline Institutional holdings & 0.640 & 0.248 & 0.599 & 0.261 & $-0.041^{* * *}$ \\
\hline CEO duality & 0.529 & 0.490 & 0.716 & 0.450 & $0.187^{* * *}$ \\
\hline Size & 7.247 & 1.643 & 6.951 & 1.67 & $-0.298^{* * *}$ \\
\hline
\end{tabular}

This table presents descriptive statistics of our sample. $\mathrm{N}=12,146$ firm-years. Panel A reports summary statistics of all variables used in our study. Panel B compares the statistics between Founder CEO and Professional CEO. ${ }^{* * *},{ }^{* *}$, and ${ }^{*}$ denote significance at the $1 \%, 5 \%$, and $10 \%$ levels in two-tailed tests. 
Table 2. Founder CEOs and Innovation

Panel A: Full Sample (Fixed Effects Regressions)

\begin{tabular}{|c|c|c|c|c|c|c|}
\hline Variables & Citations & Patents & $\begin{array}{c}\text { Economics } \\
\text { values }\end{array}$ & $\begin{array}{c}\text { Backward } \\
\text { Citations }\end{array}$ & $\begin{array}{l}\text { Non-self- } \\
\text { citations }\end{array}$ & $\begin{array}{c}\text { R\&D } \\
\text { Intensity }\end{array}$ \\
\hline Founder CEO & $\begin{array}{c}0.135^{* *} \\
{[2.48]}\end{array}$ & $\begin{array}{c}0.096^{* * *} \\
{[2.77]}\end{array}$ & $\begin{array}{c}0.227^{* * *} \\
(3.81)\end{array}$ & $\begin{array}{c}0.165^{* *} \\
(2.25)\end{array}$ & $\begin{array}{l}0.076 \\
(1.19)\end{array}$ & $\begin{array}{l}0.001 \\
(0.69)\end{array}$ \\
\hline CEO holdings & $\begin{array}{c}-0.527^{* *} \\
{[-2.15]}\end{array}$ & $\begin{array}{l}-0.054 \\
{[-0.28]}\end{array}$ & $\begin{array}{c}0.255 \\
{[1.68]}\end{array}$ & $\begin{array}{c}0.230 \\
{[0.57]}\end{array}$ & $\begin{array}{l}-0.450 \\
{[-1.17]}\end{array}$ & $\begin{array}{l}-0.019 \\
{[-1.61]}\end{array}$ \\
\hline $\mathrm{Ln}(\mathrm{CEO}$ tenure $)$ & $\begin{array}{c}-0.041^{* *} \\
{[-2.14]}\end{array}$ & $\begin{array}{l}-0.014 \\
{[-1.39]}\end{array}$ & $\begin{array}{c}-0.056^{* * *} \\
{[-2.93]}\end{array}$ & $\begin{array}{l}-0.040 \\
{[-1.90]}\end{array}$ & $\begin{array}{l}-0.028 \\
{[-1.41]}\end{array}$ & $\begin{array}{l}0.000 \\
{[0.68]}\end{array}$ \\
\hline Log(Delta) & $\begin{array}{c}0.003 \\
{[1.56]}\end{array}$ & $\begin{array}{l}0.000 \\
{[0.60]}\end{array}$ & $\begin{array}{c}0.008 \\
{[4.40]}\end{array}$ & $\begin{array}{c}0.000 \\
{[0.12]}\end{array}$ & $\begin{array}{l}-0.000 \\
{[-0.42]}\end{array}$ & $\begin{array}{l}-0.000 \\
{[-1.26]}\end{array}$ \\
\hline Female CEO & $\begin{array}{l}0.018 \\
{[0.14]}\end{array}$ & $\begin{array}{l}-0.093 \\
{[-1.35]}\end{array}$ & $\begin{array}{l}-0.112 \\
{[-1.12]}\end{array}$ & $\begin{array}{l}-0.226 \\
{[-1.56]}\end{array}$ & $\begin{array}{l}0.032 \\
{[0.24]}\end{array}$ & $\begin{array}{l}-0.005 \\
{[-1.18]}\end{array}$ \\
\hline E index & $\begin{array}{c}0.015 \\
{[1.19]}\end{array}$ & $\begin{array}{l}0.011 \\
{[1.53]}\end{array}$ & $\begin{array}{l}-0.030 \\
{[-2.45]}\end{array}$ & $\begin{array}{l}0.018 \\
{[1.10]}\end{array}$ & $\begin{array}{l}0.061 \\
{[3.90]}\end{array}$ & $\begin{array}{l}-0.000 \\
{[-0.47]}\end{array}$ \\
\hline Ln(CEO compensation) & $\begin{array}{c}0.046^{* * *} \\
{[2.89]}\end{array}$ & $\begin{array}{c}0.004 \\
{[0.53]}\end{array}$ & $\begin{array}{c}0.010 \\
{[0.83]}\end{array}$ & $\begin{array}{c}0.022 \\
{[1.28]}\end{array}$ & $\begin{array}{l}0.041 \\
{[2.54]}\end{array}$ & $\begin{array}{l}-0.000 \\
{[-0.34]}\end{array}$ \\
\hline R\&D Intensity & $\begin{array}{l}0.296^{* * *} \\
{[10.02]}\end{array}$ & $\begin{array}{c}0.051^{* * *} \\
{[4.14]}\end{array}$ & $\begin{array}{l}0.227^{* * *} \\
{[10.32]}\end{array}$ & $\begin{array}{c}0.092^{* * *} \\
{[3.49]}\end{array}$ & $\begin{array}{c}0.010^{* * *} \\
{[2.15]}\end{array}$ & \\
\hline Tobin's q & $\begin{array}{c}0.073^{* * *} \\
{[7.50]}\end{array}$ & $\begin{array}{c}0.005 \\
{[1.30]}\end{array}$ & $\begin{array}{c}0.027^{* * *} \\
{[4.04]}\end{array}$ & $\begin{array}{c}0.020^{* *} \\
{[2.53]}\end{array}$ & $\begin{array}{c}0.045^{* * *} \\
{[6.60]}\end{array}$ & $\begin{array}{c}0.002^{* * *} \\
{[6.52]}\end{array}$ \\
\hline ROA & $\begin{array}{c}-0.23 \\
{[-0.31]}\end{array}$ & $\begin{array}{l}-0.054 \\
{[-1.31]}\end{array}$ & $\begin{array}{c}0.016 \\
{[0.23]}\end{array}$ & $\begin{array}{l}-0.040 \\
{[-0.47]}\end{array}$ & $\begin{array}{l}-0.163 \\
{[-2.00]}\end{array}$ & $\begin{array}{c}-0.027^{* * *} \\
{[-10.83]}\end{array}$ \\
\hline Return & $\begin{array}{l}-0.037^{*} \\
{[-1.73]}\end{array}$ & $\begin{array}{c}-0.021^{* *} \\
{[-2.05]}\end{array}$ & $\begin{array}{c}-0.032^{* *} \\
{[-2.07]}\end{array}$ & $\begin{array}{c}-0.036^{* *} \\
{[-1.96]}\end{array}$ & $\begin{array}{l}-0.022 \\
{[-1.36]}\end{array}$ & $\begin{array}{c}-0.003^{* * *} \\
{[-3.76]}\end{array}$ \\
\hline Herfindahl index & $\begin{array}{c}0.730 \\
{[1.09]}\end{array}$ & $\begin{array}{c}-1.353^{* * *} \\
{[-4.06]}\end{array}$ & $\begin{array}{l}0.015 \\
{[0.03]}\end{array}$ & $\begin{array}{c}-1.856^{* * *} \\
{[-2.65]}\end{array}$ & $\begin{array}{l}1.151^{*} \\
{[1.85]}\end{array}$ & $\begin{array}{c}0.002 \\
{[0.09]}\end{array}$ \\
\hline Herfindahl index ${ }^{2}$ & $\begin{array}{l}-0.846 \\
{[-0.94]}\end{array}$ & $\begin{array}{c}1.106^{* * * *} \\
{[2.46]}\end{array}$ & $\begin{array}{l}-0.758 \\
{[-0.97]}\end{array}$ & $\begin{array}{l}0.780 \\
{[0.83]}\end{array}$ & $\begin{array}{l}-1.516^{*} \\
{[-1.78]}\end{array}$ & $\begin{array}{l}0.005 \\
{[0.19]}\end{array}$ \\
\hline Cash & $\begin{array}{c}-0.000^{* * * *} \\
{[3.36]}\end{array}$ & $\begin{array}{l}-0.000 \\
{[-0.01]}\end{array}$ & $\begin{array}{c}0.000^{* *} \\
{[2.18]}\end{array}$ & $\begin{array}{l}-0.000 \\
{[-0.44]}\end{array}$ & $\begin{array}{l}-0.000 \\
{[-9.56]}\end{array}$ & $\begin{array}{c}0.000 \\
{[1.32]}\end{array}$ \\
\hline CapEx & $\begin{array}{c}0.036^{* *} \\
{[2.39]}\end{array}$ & $\begin{array}{c}0.036^{* * * *} \\
{[4.17]}\end{array}$ & $\begin{array}{c}0.042^{* * * *} \\
{[2.87]}\end{array}$ & $\begin{array}{c}0.061^{* * *} \\
{[3.34]}\end{array}$ & $\begin{array}{c}0.064^{* * *} \\
{[3.92]}\end{array}$ & $\begin{array}{l}0.005^{* * *} \\
{[10.21]}\end{array}$ \\
\hline Leverage & $\begin{array}{c}-0.250^{* * * *} \\
{[-3.16]}\end{array}$ & $\begin{array}{c}-0.293^{* *} \\
{[-2.50]}\end{array}$ & $\begin{array}{l}-0.031 \\
{[-0.16]}\end{array}$ & $\begin{array}{l}-0.322 \\
{[-1.31]}\end{array}$ & $\begin{array}{c}-1.012^{* * * *} \\
{[-4.74]}\end{array}$ & $\begin{array}{l}-0.010 \\
{[-1.51]}\end{array}$ \\
\hline Ln (Firm age) & $\begin{array}{c}0.111^{* * * *} \\
{[3.15]}\end{array}$ & $\begin{array}{c}0.151^{\text {**** }} \\
{[4.58]}\end{array}$ & $\begin{array}{c}0.460^{* * * *} \\
{[7.93]}\end{array}$ & $\begin{array}{l}0.095 \\
{[1.36]}\end{array}$ & $\begin{array}{c}0.155^{* * *} \\
{[2.55]}\end{array}$ & $\begin{array}{c}0.008^{* * *} \\
{[3.71]}\end{array}$ \\
\hline CEO duality & $\begin{array}{c}0.104^{* * *} \\
{[3.18]}\end{array}$ & $\begin{array}{c}0.037^{* *} \\
{[2.17]}\end{array}$ & $\begin{array}{l}-0.021 \\
{[-0.70]}\end{array}$ & $\begin{array}{c}0.037 \\
{[1.02]}\end{array}$ & $\begin{array}{c}0.090^{* * *} \\
{[2.82]}\end{array}$ & $\begin{array}{l}-0.000 \\
{[-0.17]}\end{array}$ \\
\hline Institutional holdings & $\begin{array}{c}0.229^{* * *} \\
{[3.15]}\end{array}$ & $\begin{array}{c}0.018 \\
{[0.46]}\end{array}$ & $\begin{array}{l}0.136^{*} \\
{[1.95]}\end{array}$ & $\begin{array}{c}0.053 \\
{[0.63]}\end{array}$ & $\begin{array}{c}0.430^{* * *} \\
{[5.89]}\end{array}$ & $\begin{array}{l}-0.004^{*} \\
{[-1.83]}\end{array}$ \\
\hline Size & $\begin{array}{l}0.575^{* * *} \\
{[10.95]}\end{array}$ & $\begin{array}{l}0.253^{* * *} \\
{[10.43]}\end{array}$ & $\begin{array}{l}0.760^{* * *} \\
{[14.31]}\end{array}$ & $\begin{array}{l}0.439^{* * *} \\
{[11.68]}\end{array}$ & $\begin{array}{c}0.261^{* * *} \\
{[8.52]}\end{array}$ & $\begin{array}{c}-0.018^{* * *} \\
{[-10.15]}\end{array}$ \\
\hline Industry FE & Yes & Yes & Yes & Yes & Yes & Yes \\
\hline $\begin{array}{l}\text { Year FE } \\
\text { Observations }\end{array}$ & $\begin{array}{c}\text { Yes } \\
12.146\end{array}$ & $\begin{array}{c}\text { Yes } \\
12.146\end{array}$ & $\begin{array}{c}\text { Yes } \\
12.146\end{array}$ & $\begin{array}{c}\text { Yes } \\
12.146\end{array}$ & $\begin{array}{c}\text { Yes } \\
12.146\end{array}$ & $\begin{array}{l}\text { Yes } \\
12.146\end{array}$ \\
\hline $\mathrm{R}^{2} /$ Pseudo $\mathrm{R}^{2}$ & $56.1 \%$ & $29.8 \%$ & $37.5 \%$ & $24.3 \%$ & $52.8 \%$ & $40.5 \%$ \\
\hline
\end{tabular}


Panel B: Full Sample (Tobit Regressions)

\begin{tabular}{|c|c|c|c|c|c|c|}
\hline Variables & Citations & Patents & $\begin{array}{c}\text { Economics } \\
\text { values }\end{array}$ & $\begin{array}{l}\text { Backward } \\
\text { Citations }\end{array}$ & $\begin{array}{l}\text { Non-self- } \\
\text { citations }\end{array}$ & $\begin{array}{c}\text { R\&D } \\
\text { Intensity }\end{array}$ \\
\hline \multirow[t]{2}{*}{ Founder CEO } & $0.230^{* *}$ & $0.154^{* * *}$ & $0.226^{* *}$ & $0.215^{*}$ & $0.254^{* *}$ & 0.002 \\
\hline & [2.33] & [2.64] & {$[2.10]$} & [1.87] & {$[2.54]$} & $(0.73)$ \\
\hline \multirow[t]{2}{*}{ CEO holdings } & $-2.281^{* * * *}$ & $-1.788^{* * *}$ & $-2.729^{* * *}$ & $-4.207^{* * *}$ & $-3.336^{* * *}$ & -0.123 \\
\hline & {$[-3.88]$} & {$[4.45]$} & {$[3.50]$} & {$[-4.63]$} & {$[-4.92]$} & $(-6.16)$ \\
\hline \multirow[t]{2}{*}{$\mathrm{Ln}(\mathrm{CEO}$ tenure $)$} & $-0.089^{* *}$ & $-0.067^{* * *}$ & $-0.183^{* * *}$ & $-0.200^{* * * *}$ & $-0.074^{*}$ & 0.002 \\
\hline & {$[-2.23]$} & {$[-2.88]$} & {$[-4.31]$} & {$[-3.94]$} & {$[-1.87]$} & $(1.46)$ \\
\hline \multirow[t]{2}{*}{ Log(Delta) } & $0.010^{* * *}$ & $0.007^{* * *}$ & $0.014^{* * *}$ & $0.014^{* * *}$ & $0.010^{* * *}$ & $0.001^{* * *}$ \\
\hline & {$[2.90]$} & {$[3.88]$} & {$[4.51]$} & {$[3.75]$} & {$[3.26]$} & $(5.01)$ \\
\hline \multirow[t]{2}{*}{ Female CEO } & -0.267 & 0.058 & -0.066 & -0.023 & -0.221 & -0.007 \\
\hline & {$[-1.00]$} & [1.39] & {$[-0.26]$} & {$[-0.07]$} & {$[-0.82]$} & $(-1.19)$ \\
\hline \multirow[t]{2}{*}{ E index } & $0.094^{* * * *}$ & $0.048^{* * * *}$ & $0.079^{* * *}$ & $0.168^{* * * *}$ & $0.088^{* * * *}$ & $-0.001^{* * *}$ \\
\hline & {$[4.30]$} & {$[3.73]$} & [3.34] & {$[3.07]$} & {$[4.03]$} & $(-2.83)$ \\
\hline \multirow[t]{2}{*}{$\operatorname{Ln}(\mathrm{CEO}$ compensation $)$} & $0.091^{* * *}$ & 0.033 & {$[0.053$} & $0.136^{* * * *}$ & $0.097^{* * * *}$ & $0.009^{* * *}$ \\
\hline & {$[2.57]$} & {$[1.60]$} & {$[1.41]$} & {$[2.98]$} & {$[2.74]$} & $(8.82)$ \\
\hline \multirow[t]{2}{*}{ R\&D Intensity } & $0.830^{* * *}$ & $0.606^{* * *}$ & $0.926^{* * *}$ & $0.857^{* * *}$ & $0.854^{* * *}$ & \\
\hline & [11.11] & {$[12.72]$} & [14.99] & {$[15.77]$} & {$[12.44]$} & \\
\hline \multirow[t]{2}{*}{ Tobin's q } & $0.125^{* * *}$ & $0.065^{* * *}$ & $0.212^{* * *}$ & $-0.101^{* * *}$ & $0.118^{* * *}$ & $0.007^{* * *}$ \\
\hline & [4.53] & [7.39] & [11.59] & {$[-4.53]$} & [8.16] & $(14.81)$ \\
\hline \multirow[t]{2}{*}{ ROA } & $-0.553^{* * *}$ & $-0.295^{* * *}$ & $-0.992^{* * *}$ & $-1.438^{* * *}$ & $-0.566^{* * *}$ & $-0.152^{* * *}$ \\
\hline & {$[-3.32]$} & {$[-3.24]$} & {$[-4.42]$} & {$[-6.68]$} & {$[-3.79]$} & $(-2.57)$ \\
\hline \multirow[t]{2}{*}{ Return } & -0.068 & -0.043 & $-0.213^{* * *}$ & $-0.300^{* * *}$ & -0.043 & $-0.008^{* * *}$ \\
\hline & {$[-1.37]$} & {$[-1.60]$} & {$[-3.72]$} & {$[-4.41]$} & {$[-0.98]$} & $(-5.35)$ \\
\hline \multirow[t]{2}{*}{ Herfindahl index } & -0.629 & $-2.905^{* * *}$ & -2.465 & $-4.171^{* * *}$ & -1.389 & 0.038 \\
\hline & {$[-0.37]$} & {$[-2.93]$} & {$[-1.26]$} & {$[-4.41]$} & {$[-0.82]$} & $(0.70)$ \\
\hline \multirow[t]{2}{*}{ Herfindahl index ${ }^{2}$} & 0.140 & $2.555^{*}$ & 0.003 & 2.505 & 0.502 & -0.039 \\
\hline & {$[0.06]$} & {$[1.82]$} & {$[0.01]$} & {$[0.79]$} & {$[0.21]$} & $(-0.50)$ \\
\hline \multirow[t]{2}{*}{ Cash } & $0.000^{* * *}$ & $0.000^{* * *}$ & $0.000^{* * * *}$ & $0.000^{* * * *}$ & $0.000^{* * *}$ & $0.000^{* * *}$ \\
\hline & [3.81] & {$[5.06]$} & [2.64] & {$[5.40]$} & [3.81] & $(5.72)$ \\
\hline \multirow[t]{2}{*}{ CapEx } & $0.106^{* * *}$ & $0.112^{* * *}$ & $0.196^{* * *}$ & $0.095^{*}$ & $0.135^{* * *}$ & $0.005^{* * *}$ \\
\hline & [3.14] & {$[5.69]$} & {$[4.47]$} & {$[1.80]$} & [3.99] & $(4.46)$ \\
\hline \multirow[t]{2}{*}{ Leverage } & $-0.902^{* * *}$ & -0.192 & 0.531 & $1.263^{* *}$ & -0.067 & $-0.050^{* * *}$ \\
\hline & {$[-3.12]$} & {$[-0.68]$} & {$[1.01]$} & {$[2.08]$} & {$[-0.14]$} & $(-3.47)$ \\
\hline \multirow[t]{2}{*}{ Ln (Firm age) } & $0.130^{* * *}$ & $0.159^{* * * *}$ & $0.288^{* * *}$ & $0.287^{* * *}$ & $0.142^{* * * *}$ & $-0.004^{* * *}$ \\
\hline & {$[2.80]$} & {$[5.87]$} & {$[5.64]$} & {$[4.82]$} & {$[3.12]$} & $(-2.85)$ \\
\hline \multirow[t]{2}{*}{ CEO duality } & $0.132^{* *}$ & $0.083^{* *}$ & 0.067 & $0.308^{* * *}$ & $0.131^{* *}$ & $-0.003^{*}$ \\
\hline & {$[2.06]$} & {$[2.20]$} & {$[0.98]$} & {$[3.75]$} & {$[2.02]$} & $(-1.82)$ \\
\hline \multirow[t]{2}{*}{ Institutional holdings } & -0.234 & $0.380^{* * * *}$ & $0.539^{* * * *}$ & $0.681^{* * * *}$ & -0.226 & -0.006 \\
\hline & {$[-1.63]$} & {$[4.47]$} & {$[3.42]$} & [3.63] & {$[-1.57]$} & $(-1.39)$ \\
\hline \multirow[t]{2}{*}{ Size } & $1.201^{* * * *}$ & $0.889^{* * *}$ & $1.556^{* * * *}$ & $1.196^{* * * *}$ & $1.124^{* * * *}$ & $-0.011^{* * *}$ \\
\hline & [8.94] & {$[9.74]$} & $(7.54)$ & {$[3.02]$} & [7.09] & $(-13.77)$ \\
\hline Industry FE & Yes & Yes & Yes & Yes & Yes & Yes \\
\hline Year FE & Yes & Yes & Yes & Yes & Yes & Yes \\
\hline Observations & 12,146 & 12,146 & 12,146 & 12,146 & 12,146 & 12,146 \\
\hline $\mathrm{R}^{2} /$ Pseudo $\mathrm{R}^{2}$ & $30.8 \%$ & $39.0 \%$ & $27.7 \%$ & $29.8 \%$ & $35.5 \%$ & $54.5 \%$ \\
\hline
\end{tabular}

Panel A (B) of this table reports the results of OLS (Tobit) estimations. ${ }^{* * *},{ }^{* *}$, and ${ }^{*}$ denote significance at the $1 \%$, $5 \%$, and $10 \%$ levels in two-tailed tests. 
Table 3. First-Difference Regressions with Founder CEO Turnover

Panel A: Cumulated Forward Citations

\begin{tabular}{lcc} 
Variables & $\begin{array}{c}\Delta \text { Cumulated Citations } \\
\text { over Three Years } \\
(\mathbf{t}+\mathbf{1} \text { to } \mathbf{t}+\mathbf{3})\end{array}$ & $\begin{array}{c}\Delta \text { Cumulated Citations } \\
\text { over Three Years } \\
(\mathbf{t} \text { to } \mathbf{t}+\mathbf{2})\end{array}$ \\
\hline Founder 1 to 0 & $-0.233^{*}$ & $-0.127^{*}$ \\
& $(-1.91)$ & $(-1.76)$ \\
Control Variables & Included & Included \\
Year FE & Included & Included \\
R-sq & $34.6 \%$ & $45.3 \%$ \\
\hline
\end{tabular}

Panel B: Alternative Innovation Proxies

\begin{tabular}{lccccc} 
Variables & $\boldsymbol{\Delta}$ Citations & $\Delta$ Patents & $\begin{array}{c}\Delta \text { Economics } \\
\text { values }\end{array}$ & $\begin{array}{c}\Delta \text { Backward } \\
\text { Citations }\end{array}$ & $\begin{array}{c}\Delta \text { Non-self } \\
\text { Citations }\end{array}$ \\
\hline Founder 1 to & $-0.080^{*}$ & $-0.105^{* * *}$ & -0.058 & $-0.159^{*}$ & $-0.186^{* * *}$ \\
O & $(-1.75)$ & $(-3.00)$ & $(-1.01)$ & $(-2.36)$ & $(-2.86)$ \\
Control & Included & Included & Included & Included & Included \\
Variables & & & & & \\
Year FE & Included & Included & Included & Included & Included \\
R-sq & $45.8 \%$ & $31.5 \%$ & $48.4 \%$ & $48.5 \%$ & $51.7 \%$ \\
\hline
\end{tabular}

This table reports the results of $\log$ (Citations accumulated for three years) using a first differences model. Citations over three years is the total number of citations that have been received during the next three years (in years $t+1$ through $\mathrm{t}+3$ and years $\mathrm{t}$ through $\mathrm{t}+2$ ) by all patents applied in Year $t .{ }^{* * * *},{ }^{* *}$, and ${ }^{*}$ denote significance at the $1 \%, 5 \%$, and $10 \%$ levels in two-tailed tests. 
Table 4. Founder CEO and Innovation in New Economy vs. Old Economy Firms

Panel A: Citations

\begin{tabular}{lcc}
\hline Variables & Citations & Citations \\
\hline Founder CEO & $0.167^{* * *}$ & 0.053 \\
& $(2.79)$ & $(1.28)$ \\
New Economy & $0.806^{* * *}$ & 0.640 \\
& $(7.25)$ & $(5.73)$ \\
Founder CEO $\times$ New Economy & & $0.454^{* * *}$ \\
& & $(4.52)$ \\
\hline Control Variables & Included & Included \\
Firm \&Year FE & Included & Included \\
R-sq & $53.2 \%$ & $53.5 \%$ \\
\hline
\end{tabular}

Panel B: Alternative Innovation Proxies

\begin{tabular}{|c|c|c|c|c|c|c|c|c|}
\hline Variables & Patents & Patents & $\begin{array}{c}\text { Economics } \\
\text { values }\end{array}$ & $\begin{array}{c}\text { Economics } \\
\text { values }\end{array}$ & $\begin{array}{c}\text { Backward } \\
\text { Citations }\end{array}$ & $\begin{array}{c}\text { Backward } \\
\text { Citations }\end{array}$ & $\begin{array}{l}\text { Non-self- } \\
\text { citations }\end{array}$ & $\begin{array}{l}\text { Non-self- } \\
\text { citations }\end{array}$ \\
\hline Founder CEO & $\begin{array}{l}0.055 \\
(1.35)\end{array}$ & $\begin{array}{l}-0.170 \\
(-1.50)\end{array}$ & $\begin{array}{c}0.260^{* * *} \\
(3.56)\end{array}$ & $\begin{array}{c}0.254^{* * *} \\
(2.68)\end{array}$ & $\begin{array}{l}0.213^{* *} \\
(2.49)\end{array}$ & $\begin{array}{l}0.176^{*} \\
(1.87)\end{array}$ & $\begin{array}{l}0.119^{*} \\
(1.67)\end{array}$ & $\begin{array}{l}0.080 \\
(0.90)\end{array}$ \\
\hline New Economy & $\begin{array}{c}1.102^{* * *} \\
(4.72)\end{array}$ & $\begin{array}{c}0.902^{* * *} \\
(3.56)\end{array}$ & $\begin{array}{l}0.579^{* * *} \\
(2.14)\end{array}$ & $\begin{array}{c}0.572^{* *} \\
(2.09)\end{array}$ & $\begin{array}{c}0.859^{* * *} \\
(2.70)\end{array}$ & $\begin{array}{l}0.807^{* *} \\
(2.50)\end{array}$ & $\begin{array}{c}1.050^{* * *} \\
(3.47)\end{array}$ & $\begin{array}{l}0.773^{* *} \\
(2.53)\end{array}$ \\
\hline $\begin{array}{l}\text { Founder CEO } \times \\
\text { New Economy }\end{array}$ & & $\begin{array}{c}0.831^{* * *} \\
(5.73)\end{array}$ & & $\begin{array}{l}0.020 \\
(1.16) \\
\end{array}$ & & $\begin{array}{l}0.150^{*} \\
(1.77) \\
\end{array}$ & & $\begin{array}{c}0.797^{* * *} \\
(5.46)\end{array}$ \\
\hline Control Variables & & Included & & Included & & Included & & Included \\
\hline Firm \&Year FE & Included & Included & Included & Included & Included & Included & Included & Included \\
\hline $\mathrm{R}-\mathrm{sq}$ & $72.1 \%$ & $72.2 \%$ & $79.4 \%$ & $81.8 \%$ & $78.1 \%$ & $78.2 \%$ & $68.6 \%$ & $68.7 \%$ \\
\hline
\end{tabular}

This table reports the regressions of innovation on founder CEO for subsamples of firms classified into new vs. old economy firms by Murphy (2003). Robust standard errors clustered at the firm level are in parentheses. ${ }^{* * *},{ }^{* *}$, and ${ }^{*}$ denote significance at the $1 \%, 5 \%$, and $10 \%$ levels in two-tailed tests. 
Table 5. Founder CEO and Innovation in Litigating Risk

Panel A: Citations

\begin{tabular}{lcc}
\hline Variables & Citations & Citations \\
\hline Founder CEO & $0.159^{* *}$ & 0.005 \\
& $(2.53)$ & $(0.06)$ \\
Litigation risk & $0.200^{*}$ & 0.051 \\
& $(1.72)$ & $(0.43)$ \\
Founder CEO $\times$ Litigation risk & & $0.457^{* * *}$ \\
& & $(4.81)$ \\
\hline Control Variables & Included & Included \\
Firm \&Year FE & Included & Included \\
R-sq & $53.5 \%$ & $53.5 \%$ \\
\hline
\end{tabular}

Panel B: Alternative Innovation Proxies

\begin{tabular}{|c|c|c|c|c|c|c|c|c|}
\hline Variables & Patents & Patents & $\begin{array}{c}\text { Economics } \\
\text { values }\end{array}$ & $\begin{array}{c}\text { Economics } \\
\text { values }\end{array}$ & $\begin{array}{l}\text { Backward } \\
\text { Citations }\end{array}$ & $\begin{array}{c}\text { Backward } \\
\text { Citations }\end{array}$ & $\begin{array}{l}\text { Non-self- } \\
\text { citations }\end{array}$ & $\begin{array}{l}\text { Non-self- } \\
\text { citations }\end{array}$ \\
\hline \multirow[t]{2}{*}{ Founder CEO } & 0.087 & -0.070 & $0.160^{* * *}$ & $0.266^{* * *}$ & $0.153^{* *}$ & 0.054 & $0.134^{* *}$ & -0.030 \\
\hline & $(1.46)$ & $(-0.74)$ & $(2.09)$ & $(2.68)$ & $(2.40)$ & $(0.57)$ & $(2.16)$ & $(-0.13)$ \\
\hline \multirow[t]{2}{*}{ Litigation risk } & $0.169^{*}$ & 0.031 & $0.723^{* * *}$ & 0.310 & $0.373^{* * *}$ & -0.042 & $0.204^{*}$ & 0.055 \\
\hline & $(1.73)$ & $(0.32)$ & $(6.13)$ & $(1.24)$ & $(2.78)$ & $(-0.17)$ & $(1.85)$ & $(1.65)$ \\
\hline Founder CEO $\times$ & & $0.439^{* * *}$ & & $0.145^{* * *}$ & & $0.313^{* *}$ & & $0.459^{* * *}$ \\
\hline Litigation risk & & $(4.90)$ & & $(2.61)$ & & $(2.48)$ & & $(4.90)$ \\
\hline Control Variables & Included & Included & Included & Included & Included & Included & Included & Included \\
\hline Firm \&Year FE & Included & Included & Included & Included & Included & Included & Included & Included \\
\hline R-sq & $46.9 \%$ & $46.8 \%$ & $50.6 \%$ & $59.5 \%$ & $48.8 \%$ & $49.4 \%$ & $50.6 \%$ & $52.9 \%$ \\
\hline
\end{tabular}


Table 6. Founder CEO, Litigation Risk, and Firm Value

Panel A: Interaction Effects of Founder CEO and Litigation Risk on Firm Value

\begin{tabular}{lcc}
\hline Variables & Tobin's Q & Tobin's Q \\
\hline Founder CEO & $0.181^{* * *}$ & -0.115 \\
& $(2.86)$ & $(-1.01)$ \\
Litigation risk & -0.192 & -0.418 \\
& $(-0.67)$ & $(-1.08)$ \\
Founder CEO $\times$ Litigation risk & & $1.099^{* * *}$ \\
& & $(7.38)$ \\
\hline Control Variables & Included & Included \\
Firm \&Year FE & Included & Included \\
R-sq & $57.0 \%$ & $57.3 \%$ \\
\hline
\end{tabular}

Panel B: Interaction Effects of Founder CEO and Total Citations on Firm Value

\begin{tabular}{lcc}
\hline Variables & Tobin's Q & Tobin's Q \\
\hline Founder CEO & $0.182^{* *}$ & 0.124 \\
& $(2.00)$ & $(1.07)$ \\
Total citations & 0.153 & -0.110 \\
& $(1.73)$ & $(-1.25)$ \\
Founder CEO $\times$ Total citations & & $1.254^{* * *}$ \\
& & $(4.61)$ \\
\hline Control Variables & Included & Included \\
Firm \&Year FE & Included & Included \\
R-sq & $56.2 \%$ & $64.7 \%$ \\
\hline
\end{tabular}

In this table, Panel A reports the interaction effect of founder CEOs and firm litigation risk on firm value. To evaluate the litigation risk, we use the risk of security class action which can influence risky firm policies and managerial decisions. Panel B reports the regressions of innovation on founder CEO for subsamples of firms classified into new vs. old economy firms by Murphy (2003). Robust standard errors clustered at the firm level are in parentheses. ${ }^{* * *},{ }^{* *}$, and ${ }^{*}$ denote significance at the $1 \%, 5 \%$, and $10 \%$ levels in two-tailed tests. 
Table 7. Propensity Score Matching

Panel A: Estimates of the Average Treatment Effects (post-matching with replacement)

\begin{tabular}{|c|c|c|c|c|}
\hline Variables & Treated & Control & Difference & t-stats \\
\hline Citations & 2.432 & 2.401 & 0.031 & 1.64 \\
\hline Patents & 1.098 & 1.035 & $0.062^{*}$ & 1.66 \\
\hline Non-self citations & 1.349 & 1.353 & -0.004 & -0.15 \\
\hline Backward citations & 2.254 & 2.218 & $0.036^{*}$ & 1.79 \\
\hline
\end{tabular}


Table 8. Founder CEO and Innovation under CEOs' tenure

Panel A: Long-Tenured Founder (above median tenure)

\begin{tabular}{lccccc}
\hline Variable & Citations & Patents & $\begin{array}{c}\text { Economics } \\
\text { values }\end{array}$ & $\begin{array}{c}\text { Backward } \\
\text { Citations }\end{array}$ & $\begin{array}{c}\text { Non-self- } \\
\text { citations }\end{array}$ \\
\hline Founder CEO & 0.135 & 0.065 & 0.154 & 0.170 & 0.165 \\
& $(0.67)$ & $(0.75)$ & $(0.70)$ & $(0.94)$ & $(0.93)$ \\
\hline Control Variables & Included & Included & Included & Included & Included \\
Firm \&Year FE & Included & Included & Included & Included & Included \\
R-sq & $77.6 \%$ & $85.0 \%$ & $83.4 \%$ & $78.8 \%$ & $80.4 \%$ \\
\hline
\end{tabular}

Panel B: Short-Tenured Founder (below median tenure)

\begin{tabular}{lccccc}
\hline Variable & Citations & Patents & $\begin{array}{c}\text { Economics } \\
\text { values }\end{array}$ & $\begin{array}{c}\text { Backward } \\
\text { Citations }\end{array}$ & $\begin{array}{c}\text { Non-self- } \\
\text { citations }\end{array}$ \\
\hline Founder CEO & $0.287^{* *}$ & $0.183^{* * *}$ & $0.327^{* *}$ & $0.309^{* *}$ & $0.313^{* *}$ \\
& $(2.05)$ & $(2.69)$ & $(2.19)$ & $(2.38)$ & $(2.44)$ \\
\hline Control Variables & Included & Included & Included & Included & Included \\
Firm \&Year FE & Included & Included & Included & Included & Included \\
R-sq & $77.5 \%$ & $83.2 \%$ & $83.4 \%$ & $80.3 \%$ & $78.5 \%$ \\
\hline
\end{tabular}

This table displays the subsample tests for the firms with relatively longer- and shorter-tenured CEOs. For the test, we partition the full sample with the median CEO tenure. Robust standard errors clustered at a firm level are in parentheses. ${ }^{* * *},{ }^{* *}$, and ${ }^{*}$ denote significance at the $1 \%, 5 \%$, and $10 \%$ levels in two-tailed tests. 